\title{
Cannabidiol in Neurological and Neoplastic Diseases: Latest Developments on the Molecular Mechanism of Action
}

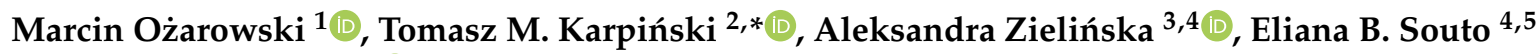 \\ and Karolina Wielgus ${ }^{1}$ (D)
}

1 Department of Biotechnology, Institute of Natural Fibres and Medicinal Plants-State Research Institute, Wojska Polskiego 71B, 60-630 Poznań, Poland; marcin.ozarowski@iwnirz.pl (M.O.); karolina.wielgus@iwnirz.pl (K.W.)

2 Chair and Department of Medical Microbiology, Poznań University of Medical Sciences, Wieniawskiego 3 , 61-712 Poznań, Poland

3 Institute of Human Genetics, Polish Academy of Sciences, Strzeszyńska 32, 60-479 Poznań, Poland; aleksandra.zielinska@igcz.poznan.pl

4 Department of Pharmaceutical Technology, Faculty of Pharmacy, University of Coimbra, Pólo das Ciências da Saúde, Azinhaga de Santa Comba, 3000-548 Coimbra, Portugal; ebsouto@ff.uc.pt

5 CEB - Center of Biological Engineering, University of Minho, Campus de Gualtar, 4710-057 Braga, Portugal

* Correspondence: tkarpin@ump.edu.pl; Tel.: +48-61-854-61-38

check for updates

Citation: Ożarowski, M.; Karpiński, T.M.; Zielińska, A.; Souto, E.B.;

Wielgus, K. Cannabidiol in

Neurological and Neoplastic

Diseases: Latest Developments on the Molecular Mechanism of Action. Int. J. Mol. Sci. 2021, 22, 4294. https:// doi.org/10.3390/ijms22094294

Academic Editor: Philippe De Deurwaerdère

Received: 24 March 2021

Accepted: 19 April 2021

Published: 21 April 2021

Publisher's Note: MDPI stays neutral with regard to jurisdictional claims in published maps and institutional affiliations.

Copyright: (c) 2021 by the authors. Licensee MDPI, Basel, Switzerland This article is an open access article distributed under the terms and conditions of the Creative Commons Attribution (CC BY) license (https:// creativecommons.org/licenses/by/ $4.0 /)$.
Abstract: As the major nonpsychotropic constituent of Cannabis sativa, cannabidiol (CBD) is regarded as one of the most promising therapeutic agents due to its proven effectiveness in clinical trials for many human diseases. Due to the urgent need for more efficient pharmacological treatments for several chronic diseases, in this review, we discuss the potential beneficial effects of CBD for Alzheimer's disease, epilepsy, multiple sclerosis, and neurological cancers. Due to its wide range of pharmacological activities (e.g., antioxidant, anti-inflammatory, and neuroprotective properties), CBD is considered a multimodal drug for the treatment of a range of neurodegenerative disorders, and various cancer types, including neoplasms of the neural system. The different mechanisms of action of CBD are here disclosed, together with recent progress in the use of this cannabis-derived constituent as a new therapeutic approach.

Keywords: Cannabis sativa; cannabidiol; CBD; mechanism of action; Alzheimer's disease; epilepsy; multiple sclerosis; cancer; pharmacological activity

\section{Introduction}

It has been long recognized that Cannabis sativa L. has a great potential for medical application for different human diseases [1,2]. Its first medical use was marked in Central Asia, including China and India, where C. sativa was used to treat several conditions nearly five millennia ago [3]. Nowadays, the therapeutic potential of phytocannabinoids and unique extracts from $C$. sativa have been the focus of interest of multiple research groups worldwide. The latest scientific reports have opened the potential therapeutic use of the main C. sativa compounds, such as delta-9-tetrahydrocannabinol ( $\left.\Delta^{9}-\mathrm{THC}\right)$ and cannabidiol (CBD). The American Food and Drug Agency (FDA) approved dronabinol and nabilone to treat chemotherapy side-effects (nausea and vomiting) and for appetite stimulation in wasting diseases. In 2018, CBD was approved for the treatment of two types of pediatric epilepsy, namely, Dravet syndrome and Lennox-Gastaut syndrome.

Cannabidiol is one of the major nonpsychotropic constituents of $C$. sativa and it is considered a promising therapeutic agent due to its already proven effectiveness against neurological diseases $[1,2,4,5]$. CBD belongs to the group of terpenophenols. This bioactive compound consists of 21 carbon atoms and, according to International Union of Pure and Applied Chemistry (IUPAC) terminology, is described as 2-[(1R,6R)-3-methyl-6-prop-1en-2-ylcyclohex-2-en-1-yl]-5-pentylbenzene-1,3-diol [6]. The structural formula for CBD 
is shown in Figure 1. The chemical activity of this Cannabis sativa-derived compound is based on the location of hydroxyl groups either in the phenolic ring (at the C- $1^{\prime}$ and C-5' positions) and the methyl group at the $\mathrm{C}-1$ position of the cyclohexene ring and the pentyl chain at the $\mathrm{C}-3^{\prime}$ of the phenolic ring. On the other hand, the ring of $\mathrm{CBD}$ is inactive in the C-4 position [6]. Thanks to hydrogen bonds, CBD has an affinity to amino acids (including threonine, tyrosine, glutamic acid, glutamine). Besides its activity in the central nervous system (CNS), other properties (e.g., anti-inflammatory, antinausea, antitumor, anticonvulsant and anxiolytic), have also been reported [7].

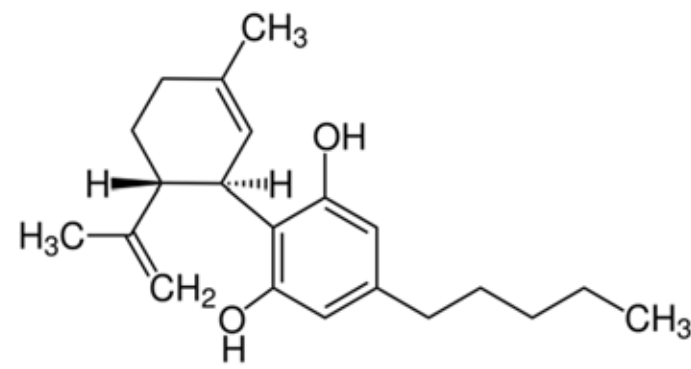

Figure 1. The structural formula of cannabidiol (CBD, $\left.\mathrm{C}_{21} \mathrm{H}_{30} \mathrm{O}_{2}\right)$.

In this review, the current state of the art knowledge is discussed with respect to the molecular mechanisms of action of CBD in Alzheimer's disease (AD), epilepsy, multiple sclerosis, and the role of $\mathrm{CBD}$ in compromising the pathological process of these diseases. The impact of CBD on many types of cancer, including neoplasms of the neural system, is also addressed.

\section{Materials and Methods}

In this review, publications available in PubMed and Scopus databases and available through the Google search engine were taken into account. The following keywords and their combinations were used: "cannabidiol", "CBD", "Alzheimer's disease", "epilepsy", "multiple sclerosis", "cancer", "neural system". Additional searches included references from identified publications. In the screening process, articles published in predatory journals and research before 1980 were excluded.

\section{Recent Developments on the Molecular Mechanism of Action of CBD for Alzheimer's Disease}

CBD is a potential bioactive for the treatment of neuroinflammatory-derived diseases, epilepsy, anxiety, and schizophrenia [8]. Due to its antioxidant, anti-inflammatory, and neuroprotective properties, cannabidiol was proposed as a promising innovative strategy for Alzheimer's disease $[9,10]$. Moreover, CBD reduces the hyperphosphorylation of tau protein [9], inhibits acetylcholinesterase activity [11], and deposition and expression of betaamyloid $[10,12,13]$. These pharmacological points of action are involved in the complex pathogenesis of Alzheimer's disease. However, the molecular mechanisms of CBD in this field are still to be fully described. A study by Huges et al. [14] described that CBD (10 $\mu \mathrm{M})$ rescued the deficit in long-term hippocampal potentiation in c57/black six mice induced by $\beta$ amyloid (Ab 1-42) by a receptor-independent mechanism, such as 5HT1A, adenosine $\mathrm{A} 2 \mathrm{~A}$, and the receptor $\mathrm{CB} 1$. $\mathrm{CBD}$ pharmacological activities were also reported to be related to diverse non-CB1/non-CB2 mechanisms $[15,16]$.

The molecular mechanism of action of $\mathrm{CBD}$ is nowadays attributed to its influence on the activity of peroxisome proliferator-activated receptor $\gamma$ (PPAR- $\gamma$ ), which belongs to the nuclear hormone receptor superfamily, and its transcription factors are activated by ligand [17]. CBD can act as a PPAR- $\gamma$ agonist [18]. Studies carried out in animal models of Alzheimer's disease showed that PPAR- $\gamma$ agonist caused, i.e., the reduction of amyloid plaque and inflammation. Furthermore, the agonist of this receptor improved cognitive and memory function in patients with mild to moderate Alzheimer's disease [19]. For this rea- 
son, CBD can be an interesting therapeutic intervention [19]. Several studies demonstrated that CBD exerts antiapoptotic activity, increases the ubiquitination of amyloid precursor protein [12], enhances the clearance of $A \beta$ peptide [20], showing anti-inflammatory and antigliosis properties [21], depending on the selective activation of PPAR- $\gamma$ (Figure 2). For this reason, CBD can be an interesting therapeutic intervention.

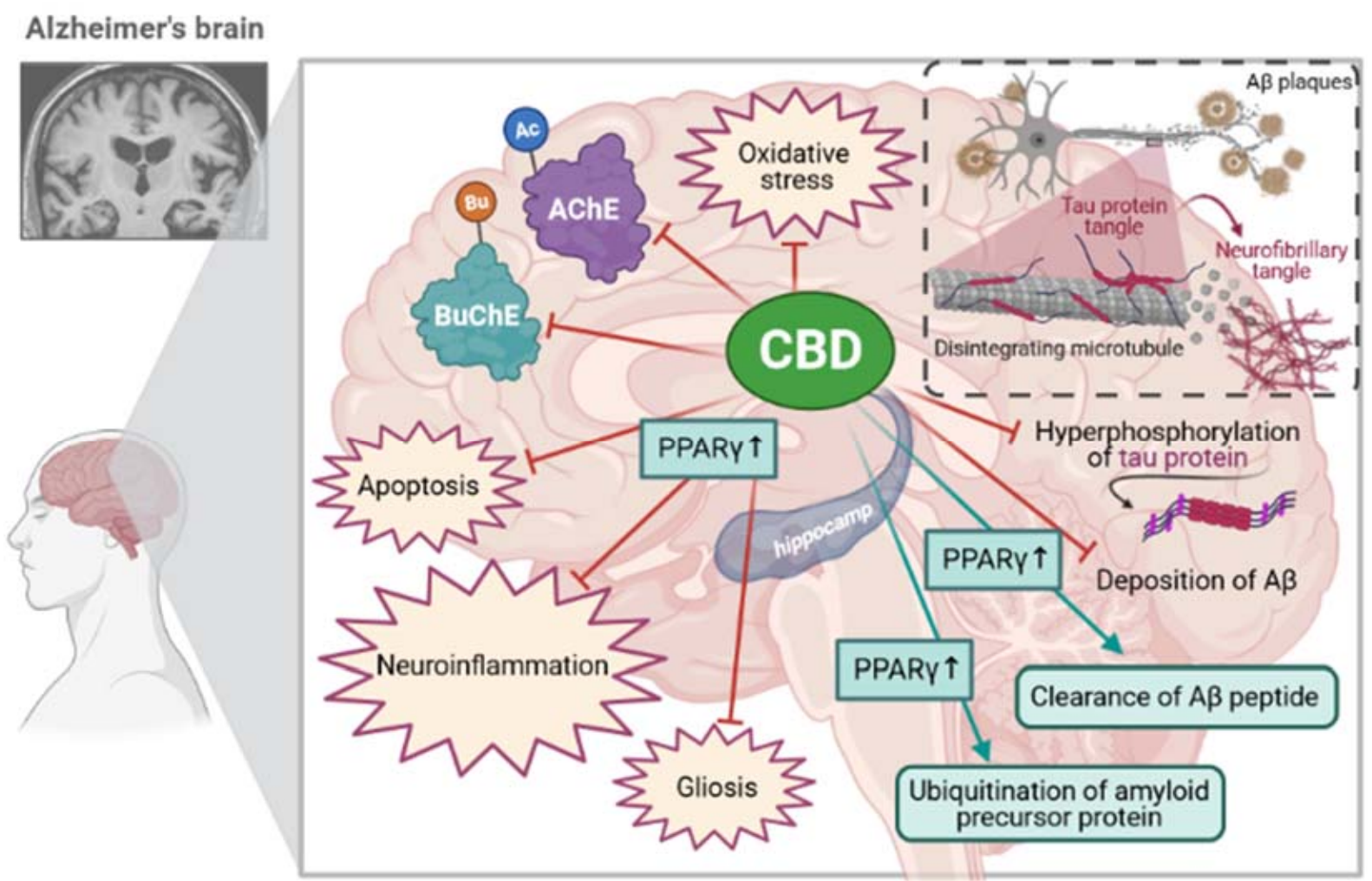

Figure 2. The role of CBD in the pathogenic mechanism of the Alzheimer's disease [own drawing]. Legends: CBD: Cannabidiol; AChE: Acetylcholinesterase; BuChE: Butyrylcholinesterase; A $\beta$ : beta-amyloid; PPAR- $\gamma$ : peroxisome proliferatoractivated receptor-gamma.

\subsection{The Effect of CBD on Acetylcholinesterase (AChE) and Cholinergic System in the Brain}

Acetylcholinesterase participates in the hydrolytic breakdown of acetylcholine in the CNS and is a target-site for cannabidiol and other bioactive chemical compounds of Cannabis sativa L. [22-25]. Recent studies have focused on explaining the basis of the interaction between $\mathrm{CBD}$ and acetylcholinesterase (AChE), a key enzyme in the pathogenesis of Alzheimer's disease [11,26]. However, many years ago, it was discovered that cannabinoids influence the limbic system by the modulation of cholinergic neuron activity in the hippocampal area [27].

\subsubsection{Mechanism of Action of CBD}

Recently, Furqan et al. [11] used the blood of humans addicted to Cannabis sativa to estimate the activity of AChE by performing an in silico study to assess the binding affinities with AChE. Analysis of the molecular docking of CBD to the binding sites of AChE showed that this cannabinoid inhibited AChE activity similarly to eight other cannabinoids. However, cannabidiol possessed the strongest effect attributed to its lipophilic properties. This in silico study confirms that CBD and other cannabinoids have promising therapeutic applications as inhibitors of AChE [11]. Moreover, another in silico study showed that all tested cannabinoids possessed the ability to inhibit both AChE and butyrylcholinesterase [25], which is a second enzyme involved in the pathogenesis of Alzheimer's disease [28]. 


\subsubsection{Pharmacological Effects of CBD in CNS}

Murillo-Rodríguez et al. [26] revealed that CBD given to rats in systemic injections $(5,10 \mathrm{or} 30 \mathrm{mg} / \mathrm{kg}$, i.p.) caused a dose-dependent effect, increasing the level of acetylcholine in the basal forebrain. A statistical significance effect was observed $6 \mathrm{~h}$ after injection of CBD at all doses; however, the highest dose $(30 \mathrm{mg} / \mathrm{kg})$ also showed the higher concentration of this neurotransmitter. Naranjo et al. [29] observed the influence of CBD on the muscarinic neurotransmission in particular sites of the rat brain involved in memory processes, in the prefrontal cortex and hippocampus, in which CBD $(10 \mathrm{mg} / \mathrm{kg}$ for three weeks) caused a normalizing effect in the expression of the choline acetyltransferase and binding density of muscarinic M1/M4 receptor, which may have positive outputs in case of memory deficits. It has already been observed that various cannabinoids can increase acetylcholine and decrease its turnover in the cortex and hippocampus of the mouse brain [30].

\subsection{Antiapoptotic Effects of CBD during Cognitive Decline}

Da Silva et al. [31] conducted a study about the effect of CBD $(10 \mathrm{mg} / \mathrm{kg}$ by intraperitoneal injection for 14 days) on the toxic effects of iron carbonyl causing severe memory deficits in rats referring to Alzheimer's, Parkinson's, and Huntington's disease.

Molecular analyses of brains showed decreasing effects of CBD on the elevated level of caspase-9, caspase-3, and cleaved poly (ADP-ribose) polymerase-1 (PARP) caused by iron carbonyl and CBD completely reversed iron-induced effects on apoptotic protease activating factor 1 (APAF1) [31]. These mechanisms of action may suggest that CBD has antiapoptotic effects during neurodegeneration. Other authors reported that $\mathrm{CBD}\left(10^{-7} \mathrm{M}\right)$ diminished apoptotic events in SHSY5YAPP+ cells through interaction with peroxisome proliferator-activated receptor $\gamma($ PPAR- $\gamma)$ [12].

\subsection{The Effect of CBD on the Beta-Amyloid Synthesis and Beta-Amyloid-Induced Toxicity}

The accumulation of extracellular aggregates of amyloid- $\beta(\mathrm{A} \beta)$ peptides in senile plaques, found in various parts of the brain, is one of the key factors of pathogenesis and progression of Alzheimer's disease [32,33] and other diseases, such as Down's syndrome, dementia with Lewy bodies, corticobasal degeneration, chronic traumatic encephalopathy [34]. It should be emphasized here that an increasing number of studies are focused on the molecular interaction of CBD with the amyloid pathway in vitro and in vivo [12-14,35-40].

Scuderi et al. [12] tested various concentrations of CBD $\left(10^{-9}-10^{-7} \mathrm{M}\right)$ in neuroblastoma cells SHSY5YAPP+ with an expression of full-length APP and, it was observed that CBD decreased fragments (C83 and C99) of amyloid precursor protein in a dose-dependent fashion and reduced the expression of $\mathrm{A} \beta$ peptide. Moreover, $\mathrm{CBD}$ can induce the ubiquitination of the amyloid precursor protein. These effects were dependent on the selective activation of peroxisome proliferator-activated receptor $\gamma($ PPAR- $\gamma)$ and this molecular mechanism may have a crucial role during the amyloidogenic pathway because activation of PPAR- $\gamma$ is associated with enhancing the clearance of $A \beta$ peptide [20]. Reducing the expression of the $\mathrm{A} \beta$ peptide by $\mathrm{CBD}$ may affect the protection of neurons against the toxic effects of this peptide positively [12]. However, Janefjord et al. [37] did not show biochemical and morphological effects of the incubation of SH-SY5Y cells with $\beta$ amyloid $(\mathrm{A} \beta \quad 1-42)$ and the CBD $(10 \mu \mathrm{M})$. Hao et al. [13] also observed that CBD was given to $\mathrm{APP} / \mathrm{PS} 1$ mice at a dose of $5 \mathrm{mg} / \mathrm{kg} / \mathrm{d}$, i.p. during 30 days, decreased the level of the A $\beta$ plaques in the hippocampus. On the other hand, Janefjord et al. [37] revealed that CBD prevented cell toxicity induced by A $\beta$ peptide, similar to other authors.

\subsection{The Effect of CBD on Hyperphosphorylated Forms of Tau Protein}

Intracellular neurofibrillary tangles composed of aggregated protein tau are the second pathological hallmark of Alzheimer's disease [35]. A few studies showed that hyperphosphorylated tau protein can be a promising target for the potential therapeutic strategy of CBD $[13,21,36,39,40]$. Previously, Esposito et al. [39] revealed that CBD $\left(10^{-7}-10^{-5} \mathrm{M}\right)$ in PC12 cells incubated with $A \beta$ inhibited the expression of the tau protein and the process 
of its hyperphosphorylation in a concentration-dependent fashion [39]. According to the authors, the observed effect is combined with a reduction in phosphorylated glycogen synthase kinase 3- $\beta$ (p-GSK3- $\beta$ ), which further leads to the rescue of the Wnt/ $\beta$ catenin pathway. It should be noted that $p$-GSK3- $\beta$ (tau protein kinase) is responsible for the hyperphosphorylation of the tau protein and the formation of neurofibrillary tangles; thus, this molecular mechanism action may be essential in this target.

\subsection{The Effect of CBD on Neuroinflammatory Processes}

\subsubsection{Pharmacological Effects of CBD in CNS}

Esposito et al. [38] reported that CBD (2.5 or $10 \mathrm{mg} / \mathrm{kg}$, i.p.), given into the right dorsal hippocampus of mice for seven days with human $A \beta$ peptide (1-42), decreased the expression of glial proinflammatory cytokine (IL-1 $\beta$ ) and inducible nitric oxide synthase (iNOS). CBD also inhibited the mRNA expression of the glial fibrillary acidic protein (GFAP, a marker of activated astrocytes) in a dose-dependent manner. These studies thus confirm that CBD has neuroprotective, anti-inflammatory, and antigliosis properties.

\subsubsection{Mechanism of Action of CBD in the Hippocampus}

Esposito et al. [21] reported that CBD $(10 \mathrm{mg} / \mathrm{kg})$ rescued CA1 pyramidal neurons in the hippocampus, induced neurogenesis in this part of the brain, and reduced reactive gliosis. The mechanism of action included the inhibition of nuclear factor-kappa $\beta$ (NFkB), as revealed by the downregulation of p50 and p65; the selective activation of PPAR- $\gamma$; diminishing the expression of GFAP, and decreasing the release of NO, IL- $1 \beta$, TNF- $\alpha$. It was shown that $\mathrm{CBD}$ inhibited the proinflammatory activity induced by the $\mathrm{A} \beta$ peptide (1-42) by PPAR- $\gamma$ [21]. Hao et al. [13] carried out an analysis of the transcriptome sequence (RNA-Seq) and differential expression analysis for the hippocampal tissues of brains of APP/PS1 mice after administration of CBD $(5 \mathrm{mg} / \mathrm{kg} / \mathrm{d}$, i.p.) for 30 days. The results showed that $\mathrm{CBD}$ upregulated the immune response possibly by $\mathrm{CB} 2$ receptors occurring in glial cells. Moreover, CBD increased the autophagy in the hippocampus, which is a promising mechanism action of $\mathrm{CBD}$ because this process is involved in pathways for $\mathrm{A} \beta$ clearance. It was revealed that $\mathrm{CBD}$ increased the expression of autophagy-related proteins (Beclin1 and LC3). The effect of this mechanism of action of CBD was the decrease in the amyloid deposition in the hippocampus. Hao et al. [13] described 231 upregulated and 131 downregulated difference expression genes. These results require further analysis to draw more consistent conclusions.

\subsubsection{Mechanism of Action of CBD in Microglia Cells}

CBD showed neuroprotective and anti-inflammatory properties by blockage of microglial activation $[8,15,41,42]$. CBD $(20 \mathrm{mg} / \mathrm{kg})$ was given to amyloid-injected mice for 3 weeks, decreased gene expression of IL-6 cytokine, decreased NO generation, and inhibited the increase in the intracellular calcium induced by ATP in cultured microglia [41]. Moreover, it was demonstrated that CBD $\left(10^{-6}\right.$ to $\left.10^{-4} \mathrm{M}\right)$ was able to inhibit NO production and expression of iNOS protein induced by A $\beta$ peptide (1-42) in PS12 cells [40]. In the observed effect of CBD, the inhibition of phosphorylated form of p38 MAP kinase was involved in the activation of transcription factor -nuclear factor-kappa $\beta$ (NFkB). Juknat et al. [15] reported that CBD diminished the LPS-dependent elevation of proinflammatory miRNAs associated with Toll-like receptor and NF- $\mathrm{KB}$ signaling, involving miR-146a, miR-155, and miR-34a.

The mechanism of action of CBD in Alzheimer's disease is summarized below (Table 1). 
Table 1. Summary of the mechanism of action in Alzheimer's disease.

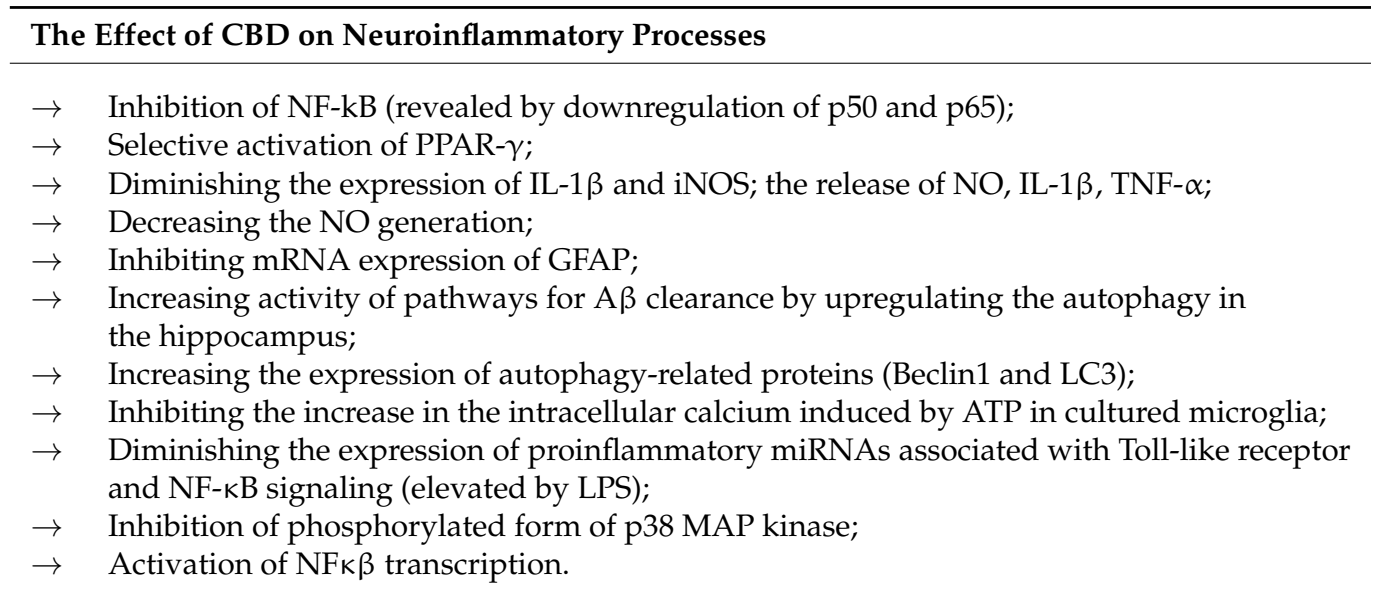

The Effect of CBD on Acetylcholinesterase (AChE) and Cholinergic System in the Brain

$\rightarrow \quad$ The ability as double inhibitors by an interaction between utilized hydrogen bonds and both catalytic triad and peripheral anionic site of AChE and BuChE;

$\rightarrow \quad$ Potency to inhibit the activity of AChE;

$\rightarrow$ Increasing the level of ACh;

$\rightarrow \quad$ Normalize effect in the expression of ChAT;

$\rightarrow \quad$ Normalize effect in the binding density of muscarinic M1/M4 receptor.
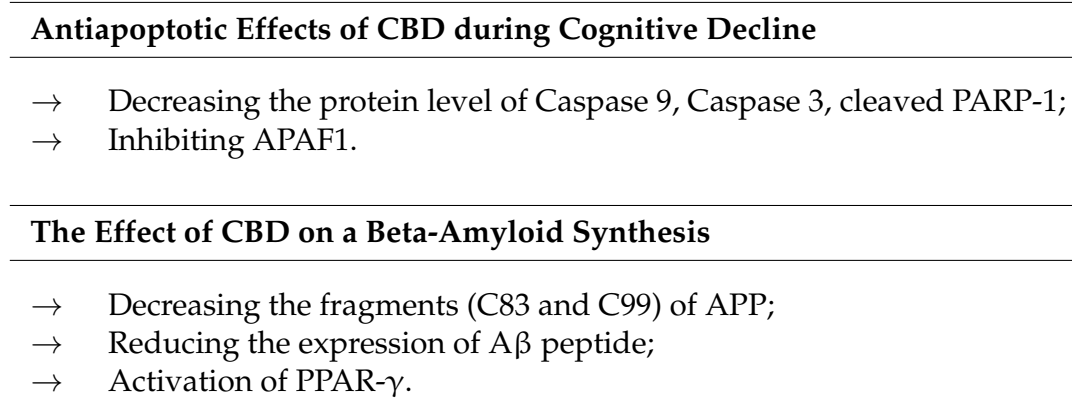

The Effect of CBD on Hyperphosphorylated Forms of Tau Protein

$\rightarrow$ Diminishing the expression of tau protein and decreasing the hyperphosphorylation;

$\rightarrow \quad$ Reducing of $\mathrm{p}$-GSK3- $\beta$ (tau protein kinase).

Legends: ACh: Acetylcholine; AChE: Acetylcholinesterase; APAF-1: Apoptotic protease activating factor 1; APP: Amyloid-beta precursor protein; BuChE: Butyrylcholinesterase; ChAT: Choline acetyltransferase; GFAB: Glial fibrillary acidic protein - marker of activated astrocytes; IL-1 $\beta$ : interleukin-1 $\beta$, proproinflammatory cytokin; iNOS: inducible nitric oxide synthase (iNOS); NFk $\beta$ : nuclear factor kappa-light-chain-enhancer of activated B cells; PARP-1: poly (ADP-ribose) polymerase-1; p-GSK3- $\beta$ : phosphorylated glycogen synthase kinase 3- $\beta$; PPAR- $\gamma$ : peroxisome proliferator-activated receptor- $\gamma$.

\section{Recent Developments on the Molecular Mechanism of Action of CBD for Epilepsy}

As a highly heterogeneous neurological disorder, epilepsy belongs to neurological diseases described by spontaneous recurrent seizures $[16,43]$. These seizures have a form of brief or long episodes characterized either by early undetectable periods or by vigorous shaking [43]. However, they can be efficiently treated in most patients using one or more antiepileptic drugs [44]. Despite the advent of new medicines that have brought more advanced and effective treatments, these are still not able to remove the prevalence of drug-resistant epilepsy.

Nabbout and Thiele [45] have reported that CBD has been proven to have antiseizure activity in studies based on in vitro and in vivo models. Consequently, in 2013, GW Pharma 
has conducted the first phase of clinical trials using Epidiolex/Epidyolex ( $>99 \%$ CBD) known as a purified form of CBD. These trials have brought beneficial results of CBD efficiency and have shown high tolerability of this compound for the treatment of drugresistant epilepsies. This, in turn, contributed to the approval as an effective drug of CBD by a US Food and Drug Administration (FDA) and the European Medicines Agency (EMA) in 2018 and 2019, respectively [46]. Both agencies have admitted that cannabis-derived compounds, such as CBD, are of great interest in the treatment of neurodegenerative diseases. Thereupon, cannabidiol has become the first FDA plant-derived compounds that can be successfully applied for the treatment of seizures in the various, rare epileptic disorders, namely: Lennox-Gastaut syndrome (LGS) or Dravet syndrome (DS) in two-yearold children (and older) with maximum doses of $10 \mathrm{mg} / \mathrm{kg}$ twice a day, and a maximum dosage of $50 \mathrm{mg} / \mathrm{kg} /$ day in adults [47]. Furthermore, the clinical trials with Epidiolex are regarded as the first open interventional exploratory study for LGS and DS. These studies have been carefully described by Nabbout and Thiele, who also mentioned the expanded access program in the USA including the treatment of CBD-resistant epilepsy in childhood and adults in the age range of 2-30 years [48]. Besides, Devinky et al. [49,50] has described clinical trials of CBD for the treatment of seizures in Dravet syndrome.

Meir and Perucca [51] have presented results that may confirm that CBD positively influences therapeutic effects in patients with epilepsy, either LGS or DS by reducing seizures. For this reason, several randomized placebo-controlled trials have been carried out as a therapy with CBD to control seizures in patients suffered from these epilepsies. According to the European Medicines Agency Public Assessment Report, all of the available evidence on the clinical consequences of the CBD influences were carefully observed and estimated by focusing on analyses of seizure outcomes in patients [51].

Lipnik-Štangelj and Razinger [52] have reviewed the actual legal framework in the European Union, which regulates cannabis-derived products for medical applications. The authors underline that although all of the requirements and marketing authorization procedures for medical products-based on plant-derived compounds for all EU were declared, there is no common regulatory framework for drugs-contained cannabinoids.

\subsection{Mode of Action of CBD in Preclinical Development}

The prevention of epilepsy development is also a great challenge for the current clinical practice, especially considering patients with a traumatic brain injury [44]. Preclinical development has proven that this bioactivity can be regarded as a potential antiepileptogenic agent. Its anticonvulsant effects tested in preclinical models highlighted the potential role of cannabis-derived constituents in treating epilepsy and its symptoms [53,54]. In vitro studies based on acute seizure models proved the anticonvulsant profile of CBD (in mice at $83.5 \mathrm{mg} / \mathrm{kg}$ up to $120 \mathrm{mg} / \mathrm{kg}$, while in rats at $88.9 \mathrm{mg} / \mathrm{kg}$ ). Preclinical tests using animal models of chronic epilepsy demonstrated the influence of CBD (up to $200 \mathrm{mg} / \mathrm{kg}$ ) on the propagation of electrically kindled limbic seizures in rats [54].

\subsection{Different Delivery Routes of CBD}

The inhaled route remains the most widely used administration route for CBD. Plasma peak concentrations rapidly occurred after aerosolization or vaporization of CBD (200-300 mg/day, for 3-18 weeks), reaching about $31 \%$ of a final bioavailability [54]. Nevertheless, this administration route requires specialized equipment, therefore multiple approaches are focused on producing the most suitable and resistant form of drug delivery [54]. On the other hand, scientific trials have shown that CBD (up to $600 \mathrm{mg}$ ) delivered orally in oil-based capsules, resulted in about $6 \%$ bioavailability [55]. Due to its low water solubility, the absorption of CBD from the gastrointestinal system is compromised, resulting in very low bioavailability. Ethosomal delivery systems have been proposed to deliver CBD by transdermal route, favored by the compound's high lipophilic character, thus preventing CBD accumulation in the skin $[54,56]$. 


\subsection{The Impact of CBD on the Central Nervous System (CNS) in Preclinical and Clinical Trials}

The focus on cannabis-derived products for the treatment of refractory epilepsy has significantly increased in recent years. As one of the major substitutes of Cannabis sativa L., CBD is recognized as a phytocannabinoid that can affect cannabinoid receptors, i.e., type 1 (CB1) and type 2 (CB2) that occur in the CNS and in the immune system [57]. Although almost a third of epilepsy patients are not effectively treated by the clinically available antiseizure drugs (ASDs), initial studies demonstrated that CBD-containing agents may be a useful treatment for pharmacoresistant epilepsy [58]. Perucca [53] reported that CBD has a well-defined anticonvulsant profile in animal models and it is mainly free from adverse psychoactive effects. The author also summarized a list of targets and actions reported for CBD. CBD may be an efficient agonist or antagonist of neurotransmitter transporters, of multiple noncannabinoid and transmembrane receptors, as well as of ion channels [59]. According to Klein et al. [58], CBD can show a positive impact on a broad spectrum of seizures. These results were obtained in the animal model. Ongoing clinical trials also indicate that therapeutic doses of purified CBD can be applied to patients suffering from epilepsy $[5,45,60]$. CBD is considered to have a great affinity for the treatment of multiple disorders, resulting in the modulation of neuronal excitability and synaptic transmission [59].

\subsubsection{Mechanisms of Action of CBD}

Among the variety of mechanisms of action of cannabidiol, receptors including CB1 and G protein-coupled receptor 55 (GPR55), the transient receptor potential vanilloid 1 (TRPV1) with $\mathrm{K}^{+}$channels and mitochondrial $\mathrm{Na}^{+} / \mathrm{Ca}^{2+}$ exchanger (NCX), are involved $[14,17]$. Due to the low affinity for endocannabinoid receptors by CBD, its mechanisms of action are mainly dependent on other molecular targets, such as TRPV1, to which the CBD shows a high affinity. TRPV1 is considered one of the most important ion channel targets [5]. The influence of CBD as an antagonist of CB1 allows the release of Gi/o protein-coupled with the reduction of TRPV1 activity. CBD can also interact with TRPV1, causing the inflow of $\mathrm{Ca}^{2+}$. Thereby a high calcium level can activate potassium channels, resulting in hyperpolarization of the presynaptic terminals. In turn, during the GPR55 activation [61], CBD as an antagonist may increase intracellular calcium via inositol 1,4,5-triphosphate (IP3) signaling. Furthermore, CBD can act on the NCX, reducing or elevating cytosolic calcium [59,62].

\subsubsection{Pharmacological Effects of CBD in CNS}

The understanding of the pharmacological effects of CBD in CNS is still incomplete. Notwithstanding, recent scientific reports regarding the application of cannabis-derived constituents in different neurological disorders, show the important role of CBD in CNS, including the modulation of $\gamma$-aminobutyric acid type $A$ receptors $\left(G_{A B A} R s\right)$ both directly and through the activation of CB1 and CB2 [63,64]. As shown in Figure 3, CBD targets (including other cannabis-derived constituents, such as THC or CBDV) are placed both at the presynaptic and postsynaptic membranes. As described by Cifelli et al. [64], CBD is responsible for modulating GABA release. Thus, CBD has an impact on presynaptic cannabinoid receptors, and additionally, it can also improve the postsynaptic activity of GABA.

As multiple randomized controlled clinical trials confirmed that Dravet and LennoxGastaut syndromes respond to CBD, cannabinoid-based treatment is commonly recommended to minimize excitatory seizure $[65,66]$. It has been proven that CBD and cannabisderived bioactives can reduce seizure attacks $[65,66]$. The mechanism of action is based on the presynaptic action on the equilibrative nucleoside transporter 1 (ENT1) adenosine pumps. Consequently, it may cause an increase in extracellular adenosine, while decreases in the GPR55 and TRPV1 receptors are also noticed [59,61]. 


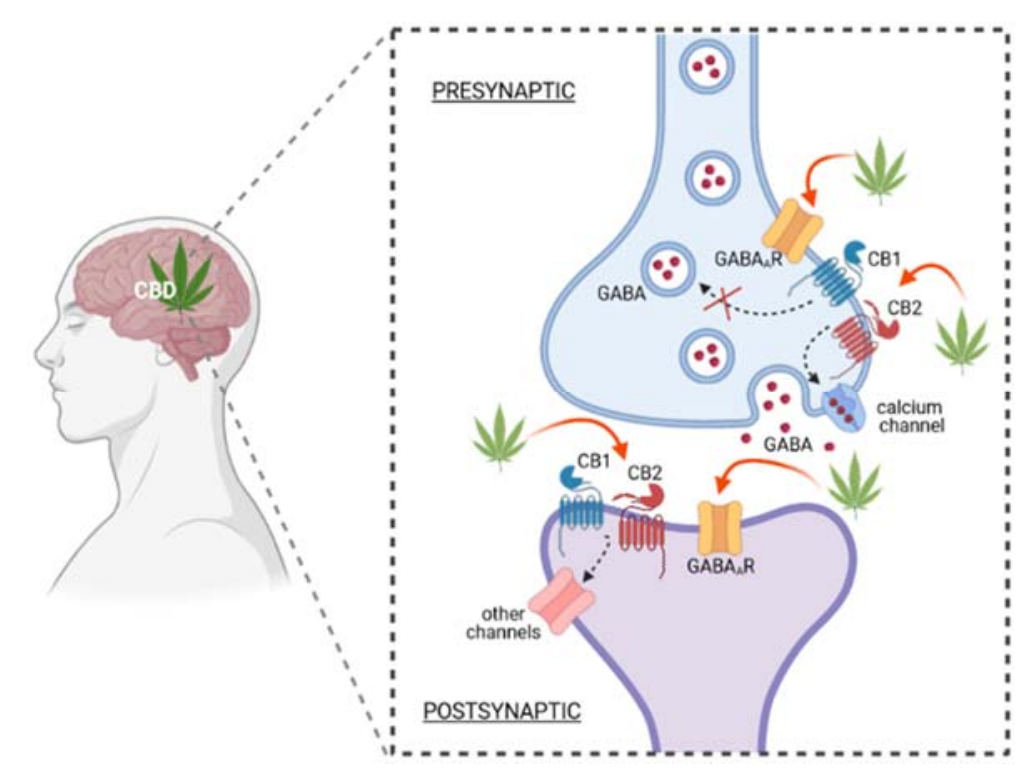

Figure legend:

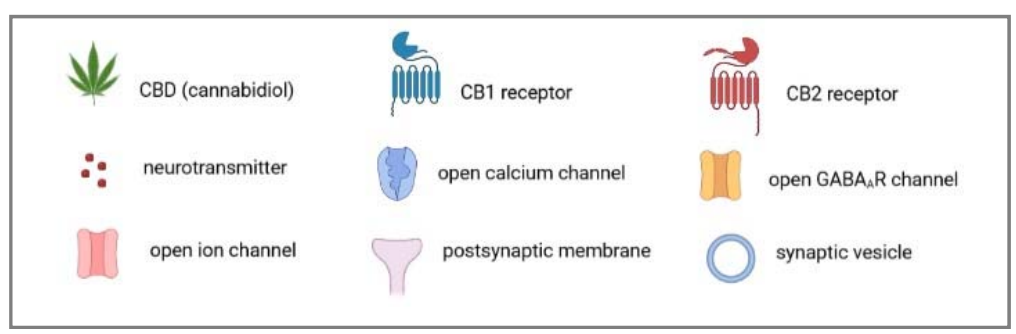

Figure 3. $\mathrm{CBD}$ mechanism of action in CNS own drawing, based on [64]. As an activator of cannabinoid receptors, $\mathrm{CBD}$ can modulate $\gamma$-aminobutyric acid type A receptor $\left(\mathrm{GABA}_{\mathrm{A}} \mathrm{R}\right)$. As shown, CBD influences presynaptic cannabinoids receptors (CB1, CB2) and improves the postsynaptic activity of GABA. Cannabis-derived constituents (e.g., CBD, THC, CBDV) may occur both at the presynaptic and postsynaptic membranes.

\subsection{Pharmaceutical Use of $C B D$}

Rosenberg et al. [65] described cannabis-based antiepileptic therapies conducted in the framework of preclinical and clinical trials of cannabinoids in epilepsy. The obtained results suggested that CBD ensures a well-tolerated, promising therapeutic for the treatment of seizures, whereas a whole-plant cannabis can reduce seizures [65]. Furthermore, selected animal models have shown promising results concerning the antiseizure or antiepileptic effects of cannabinoids. Although the main clinical trials estimate the efficacy of cannabidiol in seizure control, a partial antiseizure effect of CBD has been shown. Thus, there is a constant need for follow-up placebo-controlled, blinded, randomized clinical trials assessing the role of CBD in seizure control [54,67].

\section{Recent Developments on the Molecular Mechanism of Action of CBD for Multiple Sclerosis (MS)}

As the most common chronic autoimmune disease of the CNS, multiple sclerosis (MS), also known as encephalomyelitis disseminate, is characterized by damaged insulating covers of the nerve cells in the brain and spinal cord $[68,69]$. The ability of signal transmissions in the nervous system has failed; therefore, multiple physical, mental, or even psychiatric problems may appear. Amongst the most typical symptoms, double vision, blindness in one eye, muscle weakness, and trouble with sensation or coordination, are mentioned [70,71]. According to scientific reports, cannabis-derived medicines can decrease MS symptoms, including spasticity, neuropathic pain, tremor, and disturbed bladder function [72,73]; however, no cannabinoids are indicated for the treatment of the 
pathophysiological basis of MS. There are currently no clinical trials to ensure fully efficient CBD-based therapies for spasticity and pain in MS and their successful endpoints. These results are still limited, despite the evidence in mouse studies of encephalomyelitis (EAE), which have shown CBD as a beneficial drug. Furgiuele et al. [47] indicate a need for $e x$ vivo/in vitro studies in human immune cells to better analyze the targets acted upon by CBD in MS. Filippini et al. [74] have shown the benefits and safety of cannabis-based medicines for people with MS. These authors also indicate that the FDA has not approved any commercial application for CBD-based medicine for MS yet. Additionally, the FDA has been recently asked to place cannabis-based therapy for progressive MS on the fast track.

On the other hand, in 2014 the EMA approved the use of nabiximols for the management of moderate to severe spasticity in adults with MS. These patients have shown significant clinical improvement in the initial period with CBD-based therapy [74]. Moreover, it is worth underlining that in 2018 the Australian Government Department of Health recommended using cannabis-based medicines in the therapy of MS for adults who were observed to not obtain any markable improvements when treated using other antispasticity drugs [75].

\subsection{The Role of CBD in the Treatment of Sympthoms: Spasticity and Pain}

Several studies have been carried out to clarify the mechanisms of action through which CBD may beneficially influence MS therapy. Currently, it has not been proven that any known receptor site can be connected with CBD. Moreover, the molecular pharmacology of CBD has not been well defined yet [76]. Due to the high risk of side effects, the efficacy of treatments for MS is very limited. In the framework of different preclinical and clinical studies, cannabinoids, especially CBD, have shown immunomodulating properties. Hence, this nonpsychotropic chemical compound of Cannabis is commonly considered a promising anti-inflammatory and immunosuppressive agent. CBD seems to exhibit a better tolerability profile at high doses. To date, cannabis-based medicines have a great interest among MS patients to treat spasticity and pain [47]. A potential CBD-receptor-mediated signaling pathway is still unknown, but it has been confirmed that many of the CBD actions are related to both central and peripheral actions [76]. Although numerous CBD effects are related to both central and peripheral actions, the current research is focused on the careful identification of its mechanism. As described by Elliott et al. [77], CBD-based medicines for MS treatment were approved in some countries; nonetheless, the exact mechanism of action causing a reduction of neuroinflammation has not been described. To assay the antiinflammatory CBD, Elliott et al. [77] have used a murine model of MS as an experimental autoimmune encephalomyelitis (EAE). The obtained results proved that CBD effectively attenuated the symptoms of EAE. Additionally, a significant reduction in clinical scores of paralysis decreased T cell infiltration in the CNS, and reduced levels of IL-17 and IFN- $\gamma$ were observed [77,78] (Figure 4). CBD increased myeloid-derived suppressor cells (MDSCs) in EAE mice. Moreover, the high impact of MDSCs in CBD-mediated attenuation of EAE led to the inhibition of myelin oligodendrocyte glycoprotein (MOG)-induced proliferation of $T$ cells in vitro. Thereby, the studies confirmed that by inducing immunosuppressive MDSCs, CBD-based treatment may minimize EAR [47,77]. Besides the results obtained in rodent models of EAE that showed efficient action of CBD, more tests and clinical trials are needed to identify the action of CBD in human immune cells [47]. To sum up, CBD-enriched therapy for MS caused the reduction of relapses in EAE. Apart from a general decrease in clinical aspects, reductions in the onset of symptoms and the rate of disease progression were also noticed [78]. In some cases, improved CNS histology was also observed [47]. Mecha et al. [71] described the beneficial impact of CBD on animal models of MS. These authors also focused on the perspectives for human treatment. In turn, Yadav et al. [79] confirmed the high effectiveness of pharmacological treatments with Cannabis and its derivatives to treat spasticity and pain among patients with MS. 


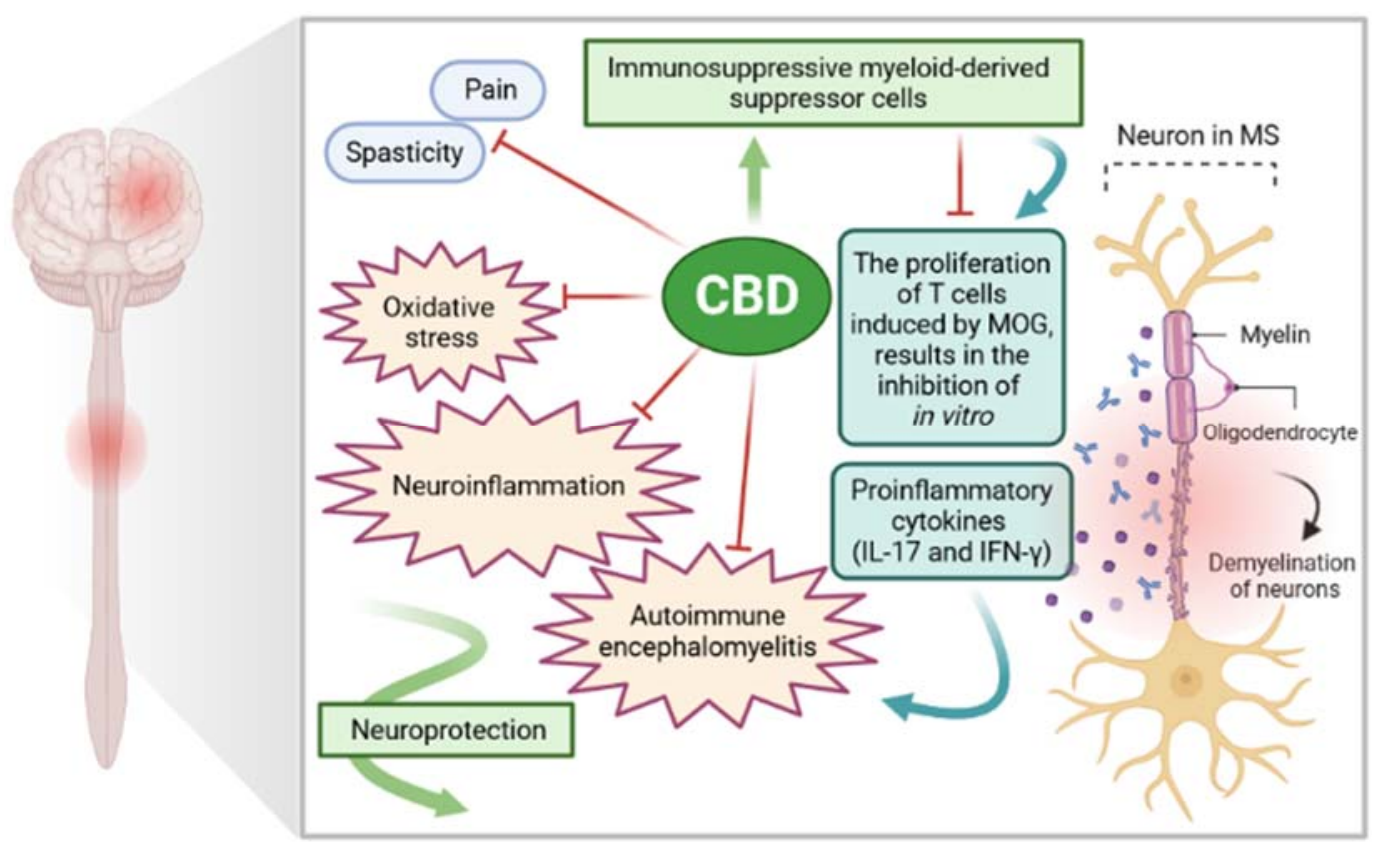

Figure 4. The role of CBD in the pathogenic mechanism of multiple sclerosis [own drawing]. Legends: CBD: Cannabidiol; MOG: Myelin oligodendrocyte glycoprotein; IL-17: Interleukin-17; IFN- $\gamma$ : Interferon-gamma.

If conventional antispastic therapy is not efficient enough, then nabiximols, commercially known as Sativex (containing CBD and THC) were mainly recommended for the treatment of pain and spasticity in MS [72], but can also be applied in inflammatory disease therapy with demyelination and neuronal injury in the brain and spinal cord. For the treatment of spasticity, Sativex was approved for the first time by the UK in 2010; however, nowadays it is recommended in more than 25 countries [47]. Interestingly, recent reports showed that the use of Cannabis is reported by $20-60 \%$ of patients with MS [47]. Furthermore, almost all of them would consider using it if it was legally approved [80,81].

\subsection{Antioxidant Properties of $C B D$}

Thanks to a polyphenolic structure, CBD belongs to the group of the most potent antioxidants. Therefore, CBD in Sativex may intensify the beneficial effects of $\Delta^{9}$-THC by reducing its psychoactive effect simultaneously. As described by Jones and Vlachou [76], the ability of CBD to inhibit the functional consequences of CB1 activation in the brain may be caused by the indirect enhancement of adenosine A1 receptors' activity through ENT inhibition. This process can clarify the lower risk of developing psychotic symptoms in patients who use preparations based on high $\Delta^{9}$-THC and CBD ratios in comparison with patients who used a lower ratio of these cannabis-derived ingredients. When patients can tolerate higher amounts of $\Delta^{9}$-THC, Sativex attenuates spasticity and pain in MS more efficiently than a pure THC dose. It has been proven that through the enhancement of glycine signaling and the inhibition of endocannabinoid degradation, $\mathrm{CBD}$ can refill the antispastic effects of $\Delta^{9}$-THC [76].

\section{Anticancer Activity of Cannabidiol (CBD)}

\subsection{Mechanisms of Action of CBD in Cancer}

CBD was shown to have effects on many types of cancer. Some neural system cancers are presented in Table 2. CBD inhibits cancer cell growth and migration and affects the disruption of F-actin integrity [82-87]. Moreover, CBD inhibits migration and invasion of endothelial cells and angiogenesis. Additionally, it downregulates proangiogenic factors [88]. The mechanism of action of CBD against cancer cells may be based on several pathways. 
CBD can promote CDKN1A (p21) expression in cells. Increased p21 protein expression evokes cell cycle arrest via cyclin D inhibition and the stimulation of GADD45A/B expression [83]. CBD can also induce endoplasmic reticulum (ER) stress [87,89], inhibiting AKT and mTOR signaling and subsequently decreasing the levels of phosphorylated mTOR and cyclin D1. CBD can inhibit the interaction between beclin-1 and Bcl-2, leading to reduction of mitochondrial membrane potential, mitochondrial $\mathrm{Ca}^{2+}$ overload, the release of cytochrome $\mathrm{c}$ to the cytosol, and activation of the intrinsic apoptotic pathway [89]. CBD also increases the generation of reactive oxygen species (ROS) [90-92]. Finally, during CBDtreatment, cancer cells can be destroyed by the induction of apoptosis and/or autophagy (Figure 5) [83,84,89,93].

Table 2. The activity of cannabidiol (CBD) against selected types of neural system cancers.

\begin{tabular}{|c|c|c|c|}
\hline Biological Target: Cancer Cells & Dose & Activity & References \\
\hline Glioma stem-like cell lines & $10-25 \mu \mathrm{M}$ & $\begin{array}{l}\text { in vitro: Decrease in cell viability, } \\
\text { induction of autophagy }\end{array}$ & [93] \\
\hline Glioma cell line U87 & $0.01-9 \mu \mathrm{M}$ & $\begin{array}{l}\text { in vitro: Inhibition of migration, no effect } \\
\text { on cell viability }\end{array}$ & [85] \\
\hline Glioma cell line U87 and U373 & $20-40 \mu \mathrm{M}$ & in vitro: Induction of apoptosis & [94] \\
\hline $\begin{array}{l}\text { Glioma cell line U87 and primary } \\
\text { glioblastoma cells MZC }\end{array}$ & $>25 \mu \mathrm{M}$ & $\begin{array}{c}\text { in vitro: Increase in calcium influx, } \\
\text { reduction of viability, induction } \\
\text { of apoptosis }\end{array}$ & [95] \\
\hline Glioma cell line U87-MG & $0.5-12 \mu \mathrm{M}$ & in vitro: Decrease in cell invasion & [96] \\
\hline $\begin{array}{l}\text { Neuroblastoma cell lines SK-N-SH25, } \\
\text { IMR-3226, NUB-627 and LAN-1 }\end{array}$ & $5-50 \mu \mathrm{g} / \mathrm{mL}$ & $\begin{array}{l}\text { in vitro: Reduction of cell viability, } \\
\text { induction of apoptosis }\end{array}$ & [84] \\
\hline SK-N-SH cells xenograft mouse model & $20 \mathrm{mg} / \mathrm{kg}$ & in vivo: Suppression of tumor growth & [84] \\
\hline Neuroblastoma celllines SH SY5Y and IMR-32 & $5-10 \mu \mathrm{M}$ & $\begin{array}{l}\text { in vitro: Induction of apoptosis, reduction } \\
\text { of cell migration and invasion, inhibition } \\
\text { of mitochondrial respiration }\end{array}$ & [97] \\
\hline $\begin{array}{l}\text { Medulloblastoma cell lines D283, D425, } \\
\text { and PER547 }\end{array}$ & $\mathrm{EC}_{50} 3.2-4.1 \mu \mathrm{M}$ & $\begin{array}{l}\text { in vitro: Elevation of ROS production, } \\
\text { induction of apoptosis and autophagy }\end{array}$ & [98] \\
\hline $\begin{array}{l}\text { Ependymoma cell lines IC-1425EPN } \\
\text { and DKFZ-EP1NS }\end{array}$ & $\mathrm{EC}_{50} 7.5-10.1 \mu \mathrm{M}$ & $\begin{array}{l}\text { in vitro: Elevation of ROS production, } \\
\text { induction of apoptosis and autophagy }\end{array}$ & [98] \\
\hline
\end{tabular}

$\mathrm{EC}_{50}$ - Half maximal effective concentration.

\subsection{Anticancer Effect of $C B D$}

In the in vitro studies, CBD induced the decrease in glioma stemlike cell viability. The half-maximal inhibitory concentration $\left(\mathrm{IC}_{50}\right)$ was between $14.6 \mu \mathrm{M}$ and $19.4 \mu \mathrm{M}$ at $24 \mathrm{~h}$ post-treatment. CBD in the lowest effective dose $(10 \mu \mathrm{M})$ reduced AKT activity in glioma stemlike cells, leading to autophagy [93]. In U87 human glioma cells, the CBD treatment for $6 \mathrm{~h}$ resulted in a concentration-dependent migration inhibition. The $\mathrm{IC}_{50}$ was $5.05 \pm 1.1 \mu \mathrm{M}$. Simultaneously, in concentrations $0.01-9 \mu \mathrm{M}$ of CBD, no effect on cell viability was observed [85]. In other studies, CBD induced apoptosis in the U87 and U373 human glioma cell lines. In the 3-(4,5-Dimethylthiazol-2-yl)-2,5-Diphenyltetrazolium Bromide (MTT) test, CBD inhibited the mitochondrial oxidative metabolism in concentrations from $5 \mu \mathrm{M}$ to $40 \mu \mathrm{M}$. The $\mathrm{IC}_{50}$ values were $26.2 \pm 2.8 \mu \mathrm{M}$ for U87 and $24.1 \pm 2.16 \mu \mathrm{M}$ for U373 cells [94]. In athymic nude mice with inoculated U87 cells, CBD-treated animals at day 18 had about $70 \%$ smaller and at day 23 about 50\% smaller tumors than in control mice [94]. Additionally, CBD induced an increase in calcium influx in U87MG cells, with an $\mathrm{EC}_{50}$ value of $22.2 \mu \mathrm{M}$. In the U87MG glioma cell line and MZC primary glioblastoma cells, CBD affected the viability of both cells at doses $>25 \mu \mathrm{M}$, inducing apoptosis [95]. CBD in concentrations of $0.5-12 \mu \mathrm{M}$ caused also decrease in U87-MG cell invasion from 
$10 \%$ to $90 \%$ [96]. Single studies showed an excellent therapeutic interaction of cannabidiol and $\gamma$-irradiation or chemoradiation $[99,100]$.

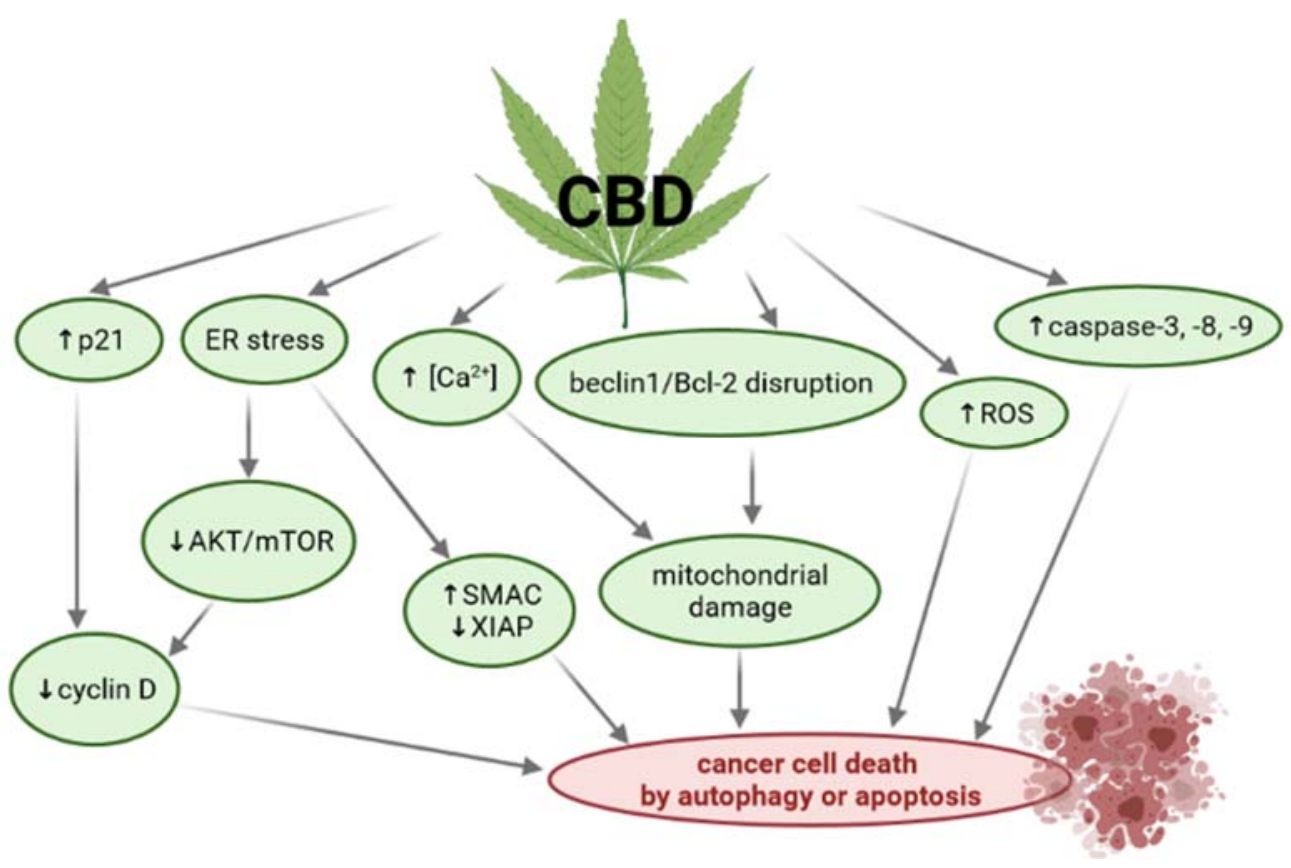

Figure 5. Pathways of anticancer activity of cannabidiol (CBD). Legends: AKT-Protein kinase B; Bcl-2-B-cell lymphoma 2; ER-endoplasmic reticulum; mTOR-the mechanistic target of rapamycin; p21—cyclin-dependent kinase inhibitor 1; ROS—reactive oxygen species; SMAC—second mitochondrial-derived activator of caspase; XIAP-X-linked inhibitor of apoptosis protein [own drawing].

In acute lymphoblastic leukemia of T lineage (T-ALL), CBD at $10 \mu \mathrm{M}$ inhibited proliferation and at 30-100 $\mu \mathrm{M}$ induced cell death. CBD at lethal concentrations caused mitochondrial $\mathrm{Ca}^{2+}$ overload and mitochondrial pore formation. In Jurkat cells, one of the leukemic cell lines, $10 \mu \mathrm{M}$ concentration of CBD induced autophagy, and $30 \mu \mathrm{M} \mathrm{CBD}$ caused mitochondrial damage and induced cytochrome $C$ release from mitochondria. $C B D$ also increased caspase- 3 and -9 activity, which confirms the impact on intrinsic apoptosis [90]. Another study showed that CBD was highly cytotoxic, with an $\mathrm{IC}_{50}$ of $12.1 \mu \mathrm{M}$. $\mathrm{CBD}$ also triggered an increase in ROS production, when compared to untreated Jurkat cells $[90,91]$.

CBD at concentrations of 5-50 $\mu \mathrm{g} / \mathrm{mL}$ effectively reduced the viability of neuroblastoma cell lines (SK-N-SH25, IMR-3226, NUB-627, and LAN-1) in a dose- and timedependent manner. Moreover, CBD led to cell arrest in the G1 phase and affected cell morphology. The cells became rounded and swollen, which confirmed that CBD induces apoptosis. In SK-N-SH cells xenograft mice treatment with $20 \mathrm{mg} / \mathrm{kg}$ of CBD suppressed tumor growth [84].

CBD induces apoptosis also in SH SY5Y and IMR-32 neuroblastoma cell lines. This activity was observed in concentrations of $5-10 \mu \mathrm{M}$. Apoptosis was related to the induction of caspase- 2 and -3 and inhibition of mitochondrial respiration. Moreover, CBD significantly reduced migration and invasion of neuroblastoma cells [97].

The next research studied three medulloblastoma cell lines (D283, D425, and PER547) and two ependymoma cell lines (IC-1425EPN and DKFZ-EP1NS). CBD had cytotoxic activity in all cancer cell lines with $\mathrm{EC}_{50}$ of 3.2-4.1 $\mu \mathrm{M}$ for medulloblastomas and 7.5-10.1 $\mu \mathrm{M}$ for ependymomas. The authors observed that CBD increases ROS production. Finally, cannabidiol leads to induction of autophagy and apoptosis by MAPK and AKT/mTOR signaling [98]. 
Thus far, CBD is not accepted by European Medicines Agency (EMA) or U.S. Food and Drug Administration (FDA) for cancer treatment. The FDA only approved Marinol and Syndros for therapeutic uses in nausea associated with cancer chemotherapy [101].

\section{Conclusions}

In this review was presented the potential role of CBD in the treatment of some neurological diseases. The strengths of this work are that it is multidisciplinarity and presents the newest data about CBD. The limitation is the relatively small number of references, which is related to the fact that $\mathrm{CBD}$ has only gained popularity in recent years.

Evidence-based knowledge on the mechanisms of action of CBD in selected neurological and neoplastic diseases, including cancers of the nervous system, was provided. Insightful analysis of the results from several pharmacological studies demonstrated that CBD can be considered a promising bioactive substance from plant sources for the effective treatment of Alzheimer's disease, epilepsy, multiple sclerosis, and neurological cancers. Recent scientific reports draw further directions for research on CBD mechanisms of action, taking into account different targets. Since some of the described mechanisms of action are still unclear, such as the antiapoptotic effects of CBD during cognitive decline or increasing the expression of autophagy-related to proteins by CBD, further studies are still in demand to draw more consistent conclusions. Thus, future studies should assess the relationship between the mechanisms of action of CBD and its therapeutic effect in clinical trials.

Author Contributions: Conceptualization, M.O. and K.W.; acquisition, analysis and interpretation of data, M.O., A.Z., T.M.K. and E.B.S.; writing—original draft preparation, M.O., A.Z., T.M.K.; K.W.; writing-review and editing, E.B.S., A.Z. and M.O.; visualization, A.Z.; supervision, K.W.; funding acquisition, T.M.K. All authors have read and agreed to the published version of the manuscript.

Funding: This research was supported by the Institute of Human Genetics, Polish Academy of Sciences by the internal grant for the implementation of a single scientific activity and by the National Centre for Research and Development by the grant ONKOKAN, INNOMED/I/11/NCBR/2014.

Institutional Review Board Statement: Not applicable.

Informed Consent Statement: Not applicable.

Data Availability Statement: Not applicable.

Conflicts of Interest: The authors declare no conflict of interest.

\section{References}

1. Makowiecka, J.; Wielgus, K. Therapeutic Potential of Cannabinoids-Retrospective and Historical Developments. J. Nat. Fibers 2014, 11, 185-198. [CrossRef]

2. Makowiecka, J.; Wielgus, K. Therapeutic Potential of Cannabinoids-Perspectives for the Future. J. Nat. Fibers 2014, 11, 283-311. [CrossRef]

3. Pertwee, R.G. Cannabinoid pharmacology: The first 66 years. Br. J. Pharmacol. 2006, 147, S163-S171. [CrossRef] [PubMed]

4. di Giacomo, V.; Chiavaroli, A.; Recinella, L.; Orlando, G.; Cataldi, A.; Rapino, M.; Di Valerio, V.; Ronci, M.; Leone, S.; Brunetti, L.; et al. Antioxidant and Neuroprotective Effects Induced by Cannabidiol and Cannabigerol in Rat CTX-TNA2 Astrocytes and Isolated Cortexes. Int. J. Mol. Sci. 2020, 21, 3575. [CrossRef] [PubMed]

5. Silvestro, S.; Mammana, S.; Cavalli, E.; Bramanti, P.; Mazzon, E. Use of Cannabidiol in the Treatment of Epilepsy: Efficacy and Security in Clinical Trials. Molecules 2019, 24, 1459. [CrossRef] [PubMed]

6. Atalay, S.; Jarocka-Karpowicz, I.; Skrzydlewska, E. Antioxidative and Anti-Inflammatory Properties of Cannabidiol. Antioxidants 2019, 9, 21. [CrossRef] [PubMed]

7. Shrader, S.H.; Tong, Y.-G.; Duff, M.B.; Freedman, J.H.; Song, Z.-H. Involvement of dopamine receptor in the actions of nonpsychoactive phytocannabinoids. Biochem. Biophys. Res. Commun. 2020, 533, 1366-1370. [CrossRef] [PubMed]

8. Fernández-Ruiz, J.; Sagredo, O.; Pazos, M.R.; García, C.; Pertwee, R.; Mechoulam, R.; Martínez-Orgado, J. Cannabidiol for neurodegenerative disorders: Important new clinical applications for this phytocannabinoid? Br. J. Clin. Pharmacol. 2013, 75, 323-333. [CrossRef] [PubMed]

9. Watt, G.; Karl, T. In vivo Evidence for Therapeutic Properties of Cannabidiol (CBD) for Alzheimer's Disease. Front. Pharmacol. 2017, 8. [CrossRef]

10. Vallée, A.; Lecarpentier, Y.; Guillevin, R.; Vallée, J.-N. Effects of cannabidiol interactions with Wnt/ $\beta$-catenin pathway and PPAR $\gamma$ on oxidative stress and neuroinflammation in Alzheimer's disease. Acta Biochim. Biophys. Sin. 2017, 49, 853-866. [CrossRef] 
11. Furqan, T.; Batool, S.; Habib, R.; Shah, M.; Kalasz, H.; Darvas, F.; Kuca, K.; Nepovimova, E.; Batool, S.; Nurulain, S.M. Cannabis Constituents and Acetylcholinesterase Interaction: Molecular Docking, In Vitro Studies and Association with CNR1 rs806368 and ACHE rs17228602. Biomolecules 2020, 10, 758. [CrossRef] [PubMed]

12. Scuderi, C.; Steardo, L.; Esposito, G. Cannabidiol Promotes Amyloid Precursor Protein Ubiquitination and Reduction of Beta Amyloid Expression in SHSY5Y APP+ Cells Through PPAR $\gamma$ Involvement. Phyther. Res. 2014, 28, 1007-1013. [CrossRef]

13. Hao, F.; Feng, Y. Cannabidiol (CBD) enhanced the hippocampal immune response and autophagy of APP/PS1 Alzheimer's mice uncovered by RNA-seq. Life Sci. 2021, 264, 118624. [CrossRef]

14. Hughes, B.; Herron, C.E. Cannabidiol Reverses Deficits in Hippocampal LTP in a Model of Alzheimer's Disease. Neurochem. Res. 2019, 44, 703-713. [CrossRef] [PubMed]

15. Juknat, A.; Gao, F.; Coppola, G.; Vogel, Z.; Kozela, E. miRNA expression profiles and molecular networks in resting and LPS-activated BV-2 microglia-Effect of cannabinoids. PLoS ONE 2019, 14, e0212039. [CrossRef] [PubMed]

16. Ibeas Bih, C.; Chen, T.; Nunn, A.V.W.; Bazelot, M.; Dallas, M.; Whalley, B.J. Molecular Targets of Cannabidiol in Neurological Disorders. Neurotherapeutics 2015, 12, 699-730. [CrossRef] [PubMed]

17. Desvergne, B.; Wahli, W. Peroxisome Proliferator-Activated Receptors: Nuclear Control of Metabolism*. Endocr. Rev. 1999, 20, 649-688. [CrossRef]

18. O'Sullivan, S.E.; Sun, Y.; Bennett, A.J.; Randall, M.D.; Kendall, D.A. Time-dependent vascular actions of cannabidiol in the rat aorta. Eur. J. Pharmacol. 2009, 612, 61-68. [CrossRef]

19. Jiang, Q.; Heneka, M.; Landreth, G.E. The Role of Peroxisome Proliferator-Activated Receptor- $\gamma$ (PPAR $\gamma)$ in Alzheimer's Disease. CNS Drugs 2008, 22, 1-14. [CrossRef]

20. Camacho, I.E. Peroxisome Proliferator-Activated Receptor Induces a Clearance Mechanism for the Amyloid-Peptide. J. Neurosci. 2004, 24, 10908-10917. [CrossRef]

21. Esposito, G.; Scuderi, C.; Valenza, M.; Togna, G.I.; Latina, V.; De Filippis, D.; Cipriano, M.; Carratù, M.R.; Iuvone, T.; Steardo, L. Cannabidiol Reduces A $\beta$-Induced Neuroinflammation and Promotes Hippocampal Neurogenesis through PPAR $\gamma$ Involvement. PLoS ONE 2011, 6, e28668. [CrossRef] [PubMed]

22. Abdel-Salam, O.M.E.; Youness, E.R.; Khadrawy, Y.A.; Sleem, A.A. Acetylcholinesterase, butyrylcholinesterase and paraoxonase 1 activities in rats treated with cannabis, tramadol or both. Asian Pac. J. Trop. Med. 2016, 9, 1089-1094. [CrossRef]

23. Abdel-Salam, O.M.E.; Khadrawy, Y.A. The Inhibition of Serum Cholinesterases by Cannabis sativa and/or Tramadol. J. Neurol. Forecast 2019, 2, 1-4.

24. Smeriglio, A.; Trombetta, D.; Alloisio, S.; Cornara, L.; Denaro, M.; Garbati, P.; Grassi, G.; Circosta, C. Promising in vitro antioxidant, anti-acetylcholinesterase and neuroactive effects of essential oil from two non-psychotropic Cannabis sativa L. biotypes. Phyther. Res. 2020, 34, 2287-2302. [CrossRef] [PubMed]

25. Karimi, I.; Yousofvand, N.; Hussein, B.A. In vitro cholinesterase inhibitory action of Cannabis sativa L. Cannabaceae and in silico study of its selected phytocompounds. Silico Pharmacol. 2021, 9, 13. [CrossRef]

26. Murillo-Rodríguez, E.; Arankowsky-Sandoval, G.; Rocha, N.B.; Peniche-Amante, R.; Veras, A.B.; Machado, S.; Budde, H. Systemic Injections of Cannabidiol Enhance Acetylcholine Levels from Basal Forebrain in Rats. Neurochem. Res. 2018, 43, 1511-1518. [CrossRef] [PubMed]

27. Miller, L.L.; Branconnier, R.J. Cannabis: Effects on memory and the cholinergic limbic system. Psychol. Bull. 1983, 93, 441-456. [CrossRef] [PubMed]

28. Greig, N.H.; Lahiri, D.K.; Sambamurti, K. Butyrylcholinesterase: An Important New Target in Alzheimer's Disease Therapy. Int. Psychogeriatr. 2002, 14, 77-91. [CrossRef]

29. Jimenez Naranjo, C.; Osborne, A.L.; Weston-Green, K. Effect of cannabidiol on muscarinic neurotransmission in the pre-frontal cortex and hippocampus of the poly I:C rat model of schizophrenia. Prog. Neuro-Psychopharmacol. Biol. Psychiatry 2019, $94,109640$. [CrossRef] [PubMed]

30. Tripathi, H.L.; Vocci, F.J.; Brase, D.A.; Dewey, W.L. Effects of cannabinoids on levels of acetylcholine and choline and on turnover rate of acetylcholine in various regions of the mouse brain. Alcohol Drug Res. 1987, 7, 525-532.

31. da Silva, V.K.; de Freitas, B.S.; Garcia, R.C.L.; Monteiro, R.T.; Hallak, J.E.; Zuardi, A.W.; Crippa, J.A.S.; Schröder, N. Antiapoptotic effects of cannabidiol in an experimental model of cognitive decline induced by brain iron overload. Transl. Psychiatry $2018,8,176$. [CrossRef]

32. Mahmoud El-Desouki, R.K. New insights on Alzheimer's disease. J. Microsc. Ultrastruct. 2014, 2, 57. [CrossRef]

33. Podtelezhnikov, A.A.; Tanis, K.Q.; Nebozhyn, M.; Ray, W.J.; Stone, D.J.; Loboda, A.P. Molecular Insights into the Pathogenesis of Alzheimer's Disease and Its Relationship to Normal Aging. PLoS ONE 2011, 6, e29610. [CrossRef]

34. Armstrong, R. Cortical laminar distribution of $\beta$-amyloid deposits in five neurodegenerative disorders. Folia Neuropathol. 2020, 58, 1-9. [CrossRef]

35. Cooray, R.; Gupta, V.; Suphioglu, C. Current Aspects of the Endocannabinoid System and Targeted THC and CBD Phytocannabinoids as Potential Therapeutics for Parkinson's and Alzheimer's Diseases: A Review. Mol. Neurobiol. 2020, 57, 4878-4890. [CrossRef]

36. Karl, T.; Garner, B.; Cheng, D. The therapeutic potential of the phytocannabinoid cannabidiol for Alzheimer's disease. Behav. Pharmacol. 2017, 28, 142-160. [CrossRef] [PubMed] 
37. Janefjord, E.; Mååg, J.L.V.; Harvey, B.S.; Smid, S.D. Cannabinoid Effects on $\beta$ Amyloid Fibril and Aggregate Formation, Neuronal and Microglial-Activated Neurotoxicity In Vitro. Cell. Mol. Neurobiol. 2014, 34, 31-42. [CrossRef]

38. Esposito, G.; Scuderi, C.; Savani, C.; Steardo, L.; De Filippis, D.; Cottone, P.; Iuvone, T.; Cuomo, V.; Steardo, L. Cannabidiol in vivo blunts $\beta$-amyloid induced neuroinflammation by suppressing IL-1 $\beta$ and iNOS expression. Br. J. Pharmacol. 2007, 151, 1272-1279. [CrossRef] [PubMed]

39. Esposito, G.; De Filippis, D.; Carnuccio, R.; Izzo, A.A.; Iuvone, T. The marijuana component cannabidiol inhibits $\beta$-amyloidinduced tau protein hyperphosphorylation through Wnt/ $\beta$-catenin pathway rescue in PC12 cells. J. Mol. Med. 2006, 84, 253-258. [CrossRef]

40. Esposito, G.; De Filippis, D.; Maiuri, M.C.; De Stefano, D.; Carnuccio, R.; Iuvone, T. Cannabidiol inhibits inducible nitric oxide synthase protein expression and nitric oxide production in $\beta$-amyloid stimulated PC12 neurons through p38 MAP kinase and NF-кB involvement. Neurosci. Lett. 2006, 399, 91-95. [CrossRef] [PubMed]

41. Martín-Moreno, A.M.; Reigada, D.; Ramírez, B.G.; Mechoulam, R.; Innamorato, N.; Cuadrado, A.; de Ceballos, M.L. Cannabidiol and Other Cannabinoids Reduce Microglial Activation In Vitro and In Vivo: Relevance to Alzheimer's Disease. Mol. Pharmacol. 2011, 79, 964-973. [CrossRef] [PubMed]

42. Ramirez, B.G. Prevention of Alzheimer's Disease Pathology by Cannabinoids: Neuroprotection Mediated by Blockade of Microglial Activation. J. Neurosci. 2005, 25, 1904-1913. [CrossRef] [PubMed]

43. Fisher, R.S.; Acevedo, C.; Arzimanoglou, A.; Bogacz, A.; Cross, J.H.; Elger, C.E.; Engel, J.; Forsgren, L.; French, J.A.; Glynn, M.; et al. ILAE Official Report: A practical clinical definition of epilepsy. Epilepsia 2014, 55, 475-482. [CrossRef]

44. Schmidt, D.; Schachter, S.C. Drug treatment of epilepsy in adults. BMJ 2014, 348, g254. [CrossRef]

45. Nabbout, R.; Thiele, E.A. The role of cannabinoids in epilepsy treatment: A critical review of efficacy results from clinical trials. Epileptic Disord. 2020, 22, 23-28. [PubMed]

46. Rubin, R. The Path to the First FDA-Approved Cannabis-Derived Treatment and What Comes Next. JAMA 2018, $320,1227$. [CrossRef] [PubMed]

47. Furgiuele, A.; Cosentino, M.; Ferrari, M.; Marino, F. Immunomodulatory Potential of Cannabidiol in Multiple Sclerosis: A Systematic Review. J. Neuroimmune Pharmacol. 2021. [CrossRef]

48. Devinsky, O.; Marsh, E.; Friedman, D.; Thiele, E.; Laux, L.; Sullivan, J.; Miller, I.; Flamini, R.; Wilfong, A.; Filloux, F.; et al. Cannabidiol in patients with treatment-resistant epilepsy: An open-label interventional trial. Lancet Neurol. 2016, 15, 270-278. [CrossRef]

49. Devinsky, O.; Patel, A.D.; Thiele, E.A.; Wong, M.H.; Appleton, R.; Harden, C.L.; Greenwood, S.; Morrison, G.; Sommerville, K. Randomized, dose-ranging safety trial of cannabidiol in Dravet syndrome. Neurology 2018, 90, e1204-e1211. [CrossRef]

50. Devinsky, O.; Cross, J.H.; Laux, L.; Marsh, E.; Miller, I.; Nabbout, R.; Scheffer, I.E.; Thiele, E.A.; Wright, S. Trial of Cannabidiol for Drug-Resistant Seizures in the Dravet Syndrome. N. Engl. J. Med. 2017, 376, 2011-2020. [CrossRef]

51. Bialer, M.; Perucca, E. Does cannabidiol have antiseizure activity independent of its interactions with clobazam? An appraisal of the evidence from randomized controlled trials. Epilepsia 2020, 61, 1082-1089. [CrossRef]

52. Lipnik-Štangelj, M.; Razinger, B. A regulatory take on cannabis and cannabinoids for medicinal use in the European Union. Arch. Ind. Hyg. Toxicol. 2020, 71, 12-18. [CrossRef]

53. Perucca, E. Cannabinoids in the Treatment of Epilepsy: Hard Evidence at Last? J. Epilepsy Res. 2017, 7, 61-76. [CrossRef] [PubMed]

54. Devinsky, O.; Cilio, M.R.; Cross, H.; Fernandez-Ruiz, J.; French, J.; Hill, C.; Katz, R.; Di Marzo, V.; Jutras-Aswad, D.; Notcutt, W.G.; et al. Cannabidiol: Pharmacology and potential therapeutic role in epilepsy and other neuropsychiatric disorders. Epilepsia 2014, 55, 791-802. [CrossRef]

55. Hawksworth, G.; McArdle, K. Metabolism and Pharmacokinetics of Cannabinoids. The Medicinal Uses of Cannabis and Cannabinoids; Guy, G.W., Whittle, B.A., Robson, P.J., Eds.; Pharmaceutical Press: London, UK, 2004; ISBN 0-85369-517-2.

56. Lodzki, M.; Godin, B.; Rakou, L.; Mechoulam, R.; Gallily, R.; Touitou, E. Cannabidiol—transdermal delivery and anti-inflammatory effect in a murine model. J. Control. Release 2003, 93, 377-387. [CrossRef] [PubMed]

57. Pagano, S.; Coniglio, M.; Valenti, C.; Federici, M.I.; Lombardo, G.; Cianetti, S.; Marinucci, L. Biological effects of Cannabidiol on normal human healthy cell populations: Systematic review of the literature. Biomed. Pharmacother. 2020, 132, 110728. [CrossRef]

58. Klein, B.D.; Jacobson, C.A.; Metcalf, C.S.; Smith, M.D.; Wilcox, K.S.; Hampson, A.J.; Kehne, J.H. Evaluation of Cannabidiol in Animal Seizure Models by the Epilepsy Therapy Screening Program (ETSP). Neurochem. Res. 2017, 42, 1939-1948. [CrossRef]

59. Gray, R.A.; Whalley, B.J. The proposed mechanisms of action of CBD in epilepsy. Epileptic Disord. 2020, 22, S10-S15. [CrossRef]

60. dos Santos, R.G.; Hallak, J.E.C.; Leite, J.P.; Zuardi, A.W.; Crippa, J.A.S. Phytocannabinoids and epilepsy. J. Clin. Pharm. Ther. 2015, 40, 135-143. [CrossRef] [PubMed]

61. Marichal-Cancino, B.A.; Fajardo-Valdez, A.; Ruiz-Contreras, A.E.; Mendez-Díaz, M.; Prospero-García, O. Advances in the Physiology of GPR55 in the Central Nervous System. Curr. Neuropharmacol. 2017, 15. [CrossRef]

62. Lazarini-Lopes, W.; Do Val-da Silva, R.A.; da Silva-Júnior, R.M.P.; Leite, J.P.; Garcia-Cairasco, N. The anticonvulsant effects of cannabidiol in experimental models of epileptic seizures: From behavior and mechanisms to clinical insights. Neurosci. Biobehav. Rev. 2020, 111, 166-182. [CrossRef]

63. Bakas, T.; van Nieuwenhuijzen, P.S.; Devenish, S.O.; McGregor, I.S.; Arnold, J.C.; Chebib, M. The direct actions of cannabidiol and 2-arachidonoyl glycerol at GABA A receptors. Pharmacol. Res. 2017, 119, 358-370. [CrossRef] 
64. Cifelli, P.; Ruffolo, G.; De Felice, E.; Alfano, V.; van Vliet, E.A.; Aronica, E.; Palma, E. Phytocannabinoids in Neurological Diseases: Could They Restore a Physiological GABAergic Transmission? Int. J. Mol. Sci. 2020, 21, 723. [CrossRef]

65. Rosenberg, E.C.; Tsien, R.W.; Whalley, B.J.; Devinsky, O. Cannabinoids and Epilepsy. Neurotherapeutics 2015, 12, 747-768. [CrossRef]

66. Kwan Cheung, K.A.; Peiris, H.; Wallace, G.; Holland, O.J.; Mitchell, M.D. The Interplay between the Endocannabinoid System, Epilepsy and Cannabinoids. Int. J. Mol. Sci. 2019, 20, 6079. [CrossRef] [PubMed]

67. Gloss, D.; Vickrey, B. Cannabinoids for epilepsy. In Cochrane Database of Systematic Reviews; Gloss, D., Ed.; John Wiley \& Sons, Ltd: Chichester, UK, 2011.

68. Hachinski, V.; Iadecola, C.; Petersen, R.C.; Breteler, M.M.; Nyenhuis, D.L.; Black, S.E.; Powers, W.J.; DeCarli, C.; Merino, J.G.; Kalaria, R.N.; et al. National Institute of Neurological Disorders and Stroke-Canadian Stroke Network Vascular Cognitive Impairment Harmonization Standards. Stroke 2006, 37, 2220-2241. [CrossRef] [PubMed]

69. Bhattacharya, A.; Mishra, R.; Tiwari, P. Multiple sclerosis: An overview. Asian Pac. J. Trop. Biomed. 2012, 2, S1954-S1962. [CrossRef]

70. Bertelson, J.; Price, B. Depression and Psychosis in Neurological Practice. Neurology in Clinical Practice: Principles of Diagnosis and Management; Bradley, W.G., Daroff, R.B., Fenichel, G.M., Jankovic, J., Eds.; Butterworth-Heinemann: Philadelphia, PA, USA, 2004; ISBN 0-7506-7469.

71. Mecha, M.; Feliú, A.; Carrillo-Salinas, F.J.; Guaza, C. Cannabidiol and Multiple Sclerosis. In Handbook of Cannabis and Related Pathologies; Elsevier: Amsterdam, The Netherlands, 2017; pp. 893-904.

72. Leussink, V.I.; Husseini, L.; Warnke, C.; Broussalis, E.; Hartung, H.-P.; Kieseier, B.C. Symptomatic therapy in multiple sclerosis: The role of cannabinoids in treating spasticity. Ther. Adv. Neurol. Disord. 2012, 5, 255-266. [CrossRef] [PubMed]

73. de Lago, E.; Gómez-Ruiz, M.; Moreno-Martet, M.; Fernández-Ruiz, J. Cannabinoids, multiple sclerosis and neuroprotection. Expert Rev. Clin. Pharmacol. 2009, 2, 645-660. [CrossRef]

74. Filippini, G.; Lasserson, T.; Dwan, K.; Borrelli, F.; Izzo, A.; Minozzi, S. Cannabis and cannabinoids for people with multiple sclerosis. Cochrane Database Syst. Rev. 2019, 2019. [CrossRef]

75. Australian Government Guidance for the Use of Medicinal Cannabis in the Treatment of Multiple Sclerosis in Australia. Available online: https:/ / www.tga.gov.au/publication/guidance-use-medicinal-cannabis-treatment-multiple-sclerosis-australia (accessed on 15 May 2019).

76. Jones, É.; Vlachou, S. A Critical Review of the Role of the Cannabinoid Compounds $\Delta 9$-Tetrahydrocannabinol ( $\Delta 9-\mathrm{THC})$ and Cannabidiol (CBD) and their Combination in Multiple Sclerosis Treatment. Molecules 2020, 25, 4930. [CrossRef]

77. Elliott, D.M.; Singh, N.; Nagarkatti, M.; Nagarkatti, P.S. Cannabidiol Attenuates Experimental Autoimmune Encephalomyelitis Model of Multiple Sclerosis Through Induction of Myeloid-Derived Suppressor Cells. Front. Immunol. 2018, 9. [CrossRef]

78. Nichols, J.M.; Kummari, E.; Sherman, J.; Yang, E.-J.; Dhital, S.; Gilfeather, C.; Yray, G.; Morgan, T.; Kaplan, B.L.F. CBD Suppression of EAE Is Correlated with Early Inhibition of Splenic IFN- $\gamma+$ CD8+ T Cells and Modest Inhibition of Neuroinflammation. J. Neuroimmune Pharmacol. 2020. [CrossRef]

79. Yadav, V.; Bever, C.; Bowen, J.; Bowling, A.; Weinstock-Guttman, B.; Cameron, M.; Bourdette, D.; Gronseth, G.S.; Narayanaswami, P. Summary of evidence-based guideline: Complementary and alternative medicine in multiple sclerosis: Report of the Guideline Development Subcommittee of the American Academy of Neurology. Neurology 2014, 82, 1083-1092. [CrossRef] [PubMed]

80. Schabas, A.; Vukojevic, V.; Taylor, C.; Thu, Z.; Badyal, A.; Chan, J.; Devonshire, V.; Traboulsee, A.; Sayao, A.; Carruthers, R. Cannabis-based product use in a multiple sclerosis cohort. Mult. Scler. J. Exp. Transl. Clin. 2019, 5, 205521731986936. [CrossRef] [PubMed]

81. Banwell, E.; Pavisian, B.; Lee, L.; Feinstein, A. Attitudes to cannabis and patterns of use among Canadians with multiple sclerosis. Mult. Scler. Relat. Disord. 2016, 10, 123-126. [CrossRef] [PubMed]

82. Anis, O.; Vinayaka, A.C.; Shalev, N.; Namdar, D.; Nadarajan, S.; Anil, S.M.; Cohen, O.; Belausov, E.; Ramon, J.; Mayzlish Gati, E.; et al. Cannabis-Derived Compounds Cannabichromene and $\Delta 9$-Tetrahydrocannabinol Interact and Exhibit Cytotoxic Activity against Urothelial Cell Carcinoma Correlated with Inhibition of Cell Migration and Cytoskeleton Organization. Molecules 2021, 26, 465. [CrossRef]

83. Go, Y.Y.; Kim, S.R.; Kim, D.Y.; Chae, S.-W.; Song, J.-J. Cannabidiol enhances cytotoxicity of anti-cancer drugs in human head and neck squamous cell carcinoma. Sci. Rep. 2020, 10, 20622. [CrossRef] [PubMed]

84. Fisher, T.; Golan, H.; Schiby, G.; PriChen, S.; Smoum, R.; Moshe, I.; Peshes-Yaloz, N.; Castiel, A.; Waldman, D.; Gallily, R.; et al. In Vitro and In Vivo Efficacy of Non-Psychoactive Cannabidiol in Neuroblastoma. Curr. Oncol. 2016, 23, 15-22. [CrossRef] [PubMed]

85. Vaccani, A.; Massi, P.; Colombo, A.; Rubino, T.; Parolaro, D. Cannabidiol inhibits human glioma cell migration through a cannabinoid receptor-independent mechanism. Br. J. Pharmacol. 2005, 144, 1032-1036. [CrossRef]

86. Marinelli, O.; Morelli, M.B.; Annibali, D.; Aguzzi, C.; Zeppa, L.; Tuyaerts, S.; Amantini, C.; Amant, F.; Ferretti, B.; Maggi, F.; et al. The Effects of Cannabidiol and Prognostic Role of TRPV2 in Human Endometrial Cancer. Int. J. Mol. Sci. 2020, 21, 5409. [CrossRef]

87. Jeong, S.; Jo, M.J.; Yun, H.K.; Kim, D.Y.; Kim, B.R.; Kim, J.L.; Park, S.H.; Na, Y.J.; Jeong, Y.A.; Kim, B.G.; et al. Cannabidiol promotes apoptosis via regulation of XIAP/Smac in gastric cancer. Cell Death Dis. 2019, 10, 846. [CrossRef]

88. Solinas, M.; Massi, P.; Cantelmo, A.; Cattaneo, M.; Cammarota, R.; Bartolini, D.; Cinquina, V.; Valenti, M.; Vicentini, L.; Noonan, D.; et al. Cannabidiol inhibits angiogenesis by multiple mechanisms. Br. J. Pharmacol. 2012, 167, 1218-1231. [CrossRef] [PubMed] 
89. Shrivastava, A.; Kuzontkoski, P.M.; Groopman, J.E.; Prasad, A. Cannabidiol Induces Programmed Cell Death in Breast Cancer Cells by Coordinating the Cross-talk between Apoptosis and Autophagy. Mol. Cancer Ther. 2011, 10, 1161-1172. [CrossRef]

90. Olivas-Aguirre, M.; Torres-López, L.; Valle-Reyes, J.S.; Hernández-Cruz, A.; Pottosin, I.; Dobrovinskaya, O. Cannabidiol directly targets mitochondria and disturbs calcium homeostasis in acute lymphoblastic leukemia. Cell Death Dis. 2019, 10, 779. [CrossRef]

91. Olivas-Aguirre, M.; Torres-López, L.; Pottosin, I.; Dobrovinskaya, O. Phenolic Compounds Cannabidiol, Curcumin and Quercetin Cause Mitochondrial Dysfunction and Suppress Acute Lymphoblastic Leukemia Cells. Int. J. Mol. Sci. 2020, 22, 204. [CrossRef]

92. Jeong, S.; Yun, H.K.; Jeong, Y.A.; Jo, M.J.; Kang, S.H.; Kim, J.L.; Kim, D.Y.; Park, S.H.; Kim, B.R.; Na, Y.J.; et al. Cannabidiol-induced apoptosis is mediated by activation of Noxa in human colorectal cancer cells. Cancer Lett. 2019, 447, 12-23. [CrossRef] [PubMed]

93. Nabissi, M.; Morelli, M.B.; Amantini, C.; Liberati, S.; Santoni, M.; Ricci-Vitiani, L.; Pallini, R.; Santoni, G. Cannabidiol stimulates Aml-1a-dependent glial differentiation and inhibits glioma stem-like cells proliferation by inducing autophagy in a TRPV2dependent manner. Int. J. Cancer 2015, 137, 1855-1869. [CrossRef] [PubMed]

94. Massi, P.; Vaccani, A.; Ceruti, S.; Colombo, A.; Abbracchio, M.P.; Parolaro, D. Antitumor Effects of Cannabidiol, a Nonpsychoactive Cannabinoid, on Human Glioma Cell Lines. J. Pharmacol. Exp. Ther. 2004, 308, 838-845. [CrossRef]

95. Nabissi, M.; Morelli, M.B.; Santoni, M.; Santoni, G. Triggering of the TRPV2 channel by cannabidiol sensitizes glioblastoma cells to cytotoxic chemotherapeutic agents. Carcinogenesis 2013, 34, 48-57. [CrossRef] [PubMed]

96. Solinas, M.; Massi, P.; Cinquina, V.; Valenti, M.; Bolognini, D.; Gariboldi, M.; Monti, E.; Rubino, T.; Parolaro, D. Cannabidiol, a Non-Psychoactive Cannabinoid Compound, Inhibits Proliferation and Invasion in U87-MG and T98G Glioma Cells through a Multitarget Effect. PLoS ONE 2013, 8, e76918. [CrossRef] [PubMed]

97. Alharris, E.; Singh, N.P.; Nagarkatti, P.S.; Nagarkatti, M. Role of miRNA in the regulation of cannabidiol-mediated apoptosis in neuroblastoma cells. Oncotarget 2019, 10, 45-59. [CrossRef] [PubMed]

98. Andradas, C.; Byrne, J.; Kuchibhotla, M.; Ancliffe, M.; Jones, A.C.; Carline, B.; Hii, H.; Truong, A.; Storer, L.C.D.; Ritzmann, T.A.; et al. Assessment of Cannabidiol and $\Delta$ 9-Tetrahydrocannabiol in Mouse Models of Medulloblastoma and Ependymoma. Cancers 2021, 13, 330. [CrossRef] [PubMed]

99. Dall'Stella, P.B.; Docema, M.F.L.; Maldaun, M.V.C.; Feher, O.; Lancellotti, C.L.P. Case Report: Clinical Outcome and Image Response of Two Patients with Secondary High-Grade Glioma Treated With Chemoradiation, PCV, and Cannabidiol. Front. Oncol. 2019, 8. [CrossRef] [PubMed]

100. Ivanov, V.N.; Wu, J.; Wang, T.J.C.; Hei, T.K. Inhibition of ATM kinase upregulates levels of cell death induced by cannabidiol and $\gamma$-irradiation in human glioblastoma cells. Oncotarget 2019, 10, 825-846. [CrossRef] [PubMed]

101. FDA and Cannabis: Research and Drug Approval Process. Available online: https://www.fda.gov/news-events/public-healthfocus/fda-and-cannabis-research-and-drug-approval-process (accessed on 2 April 2021). 